\title{
The potential of new measurement and modelling techniques in alpine cryosphere and geomorphology research
}

\author{
Christian Hauck, Claude Collet, Reynald Delaloye, \\ Christin Hilbich, Martin Hoelzle, Matthias Huss, \\ Nadine Salzmann, Fribourg
}

\section{Introduction}

The term global change comprises a multitude of different concepts, phenomena and developments on very different spatial and temporal scales and concerning many different but interrelated disciplines. Relating global or globally relevant phenomena to site-specific processes on a regional to local scale in Switzerland is not always feasible; however, cryospheric processes and their relation to climate and hydrology may be considered an exception.

The cryosphere, comprising ice sheets and ice shelves, sea ice, glaciers, snow and permafrost plays a key role in the climate system due to (i) its large-scale influence on the radiation balance, (ii) the coupling between atmosphere, oceans and subsurface as well as (iii) the hydrological cycle. In mountain areas, such as the European Alps, with small to regional scale distribution of cryospheric components, i.e. glaciers, snow and permafrost, climate is the main driver of their behaviour and may therefore induce strong impacts and feedbacks on the investigated scale range. In order to assess these climate impacts on cryosphere with sufficient reliability, the corresponding hydrological, geomorphological and geotechnical changes, and their consequences and risks for environment and society, as well as the relevant processes that determine the interactions between the alpine cryosphere, atmosphere and hydrosphere have to be known.

To be able to analyse climate-cryosphere interactions, both novel monitoring and modelling tools are necessary. Cryospheric components in high mountain areas are only seldom included in global or regional scale climate models on scales that are sufficient for climate impact studies in small regions like the Swiss Alps (e.g. Kotlarski et al. 2010a, 2010b; Paul \& Kotlarski 2010). Specialised cryospheric models have therefore to be developed and coupled to the results of state-of-the-art Global or Regional Climate Models (GCM, RCM)(e.g. Engelhardt et al. 2010; Machguth et al. 2009). Similarly, new monitoring techniques are being developed for operational and long-term cryospheric data acquisition in high mountain areas. Here, a current focus lies on properties which cannot be monitored from space, e.g. subsurface ice content (permafrost) (HAUcK et al. 2011) and spatially heterogeneous snow accumulation for glacier mass balance (MACHGUTH et al. 2006a).

At the Department of Geosciences of the University of the Fribourg, three research groups (within Physical Geography and Geomatics) are currently concerned with developing new tools for glacier and permafrost monitoring and modelling. In this contribution, these new approaches will be presented, and their general applicability will be discussed. In addition, applications to interdisciplinary research questions, such as future water availability and the assessment of potential risks through thawing permafrost slopes in the Swiss Alps will be presented.

\section{Alpine cryosphere and global change}

During the last century atmospheric warming has caused changes in almost all cryospheric components in the European Alps, including major retreat of mountain glaciers, increase of firn temperatures at high elevations, a decline of snow cover duration on low elevation sites and permafrost degradation at sites where ground ice contents are low and permafrost temperatures are close to the melting point (GRUBER \& Haeberli 2007; Harris et al. 2009; Hilbich et al. 2008; Hoelzle et al. 2011; LATERnSER \& SchneEBeli 2003; WGMS 2009). Temporal and spatial changes in snow and ice distribution in mountain regions can strongly influence the hydrological cycle as well as the stability of frozen ground material, and can thus have an impact on the management of water resources or natural hazards on regional to national scales (BARNETT et al. 2005; Bommer et al. 2010; Huss 2011; K̈̈̈̈в et al. 2005; STAHL et al. 2008).

\subsection{Development of new monitoring and modelling techniques}

\subsubsection{Monitoring techniques}

Monitoring techniques can be divided into direct (insitu) and indirect methods, the latter being subdivided into surface-based, airborne or spaceborne (satellite) methods. Direct methods include temperature measurements in boreholes (snow, ice, ground), snow depth measurements in snow pits or direct (point-) observations of accumulation and ablation rates on glaciers. All these methods have the advantages of (1) being simple to apply with only little data processing required and 

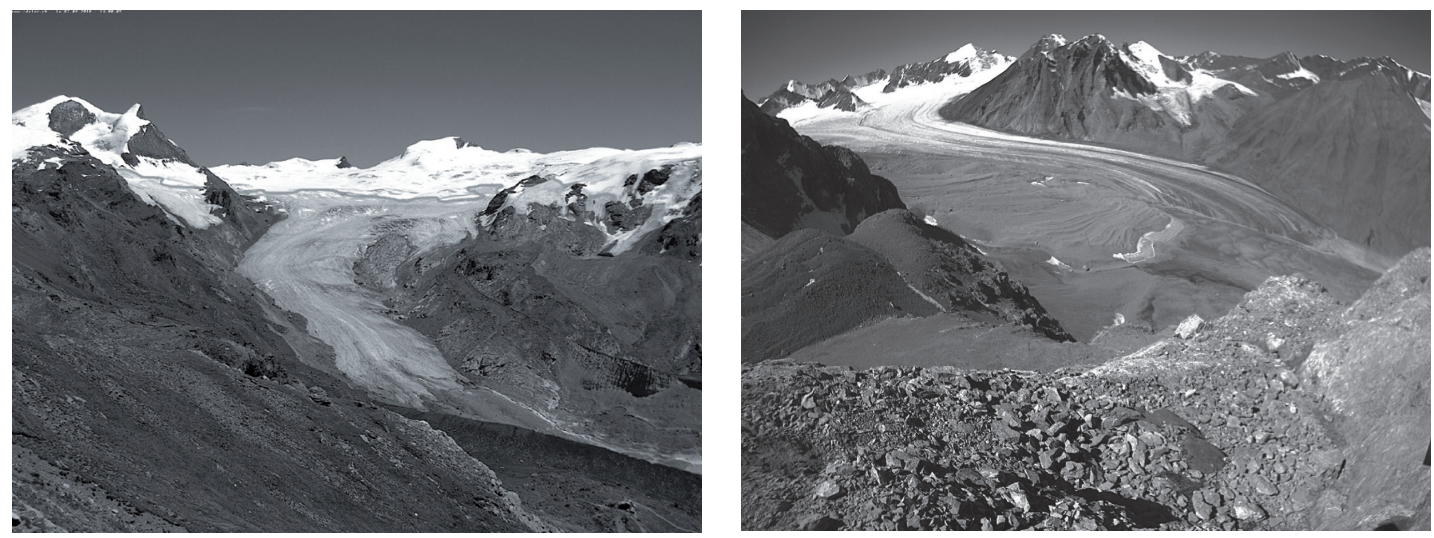

Fig. 1: (left) Picture from the automatic camera at Findelen glacier, 8th August 2010. The grey line indicates the snow line. (right) Picture from the automatic camera at Abramov glacier, 5th September 2011.

Links: Bild der automatischen Kamera am Findelengletscher, 8. August 2010. Die Linie kennzeichnet die aktuelle Schneegrenze. Rechts: Bild der automatischen Kamera am Abramov Gletscher, 5. September 2011.

Image prise par la caméra automatique sur le glacier de Findelen, 8 août 2010 (à gauche). La ligne grise indique la limite de la neige. Image prise par la caméra automatique sur le glacier Abramov, 5 septembre 2011 (à droite).

(2) having a comparatively high data accuracy. On the other hand, they also have the similar disadvantage of being only point measurements in space with almost little potential for generalisation to larger areas.

In contrast, indirect methods such as geophysical techniques and remote sensing can resolve cryospheric variables on larger spatial scales, both horizontally and vertically, but with higher demands on data processing and usually larger interpretational uncertainty. Typical examples are satellite-based cryospheric monitoring (e.g. KÄÄв 2005; КӒÄв et al. 2007; STRozZI et al. 2009) or applied geophysical methods for subsurface investigations of glaciers and permafrost (KULEsSA \& WooDWARD 2007; HaUcK \& KNeISEl 2008).

At the University of Fribourg, the Department of Geosciences participates in three cryospheric monitoring networks: (i) the World Glacier Monitoring Service WGMS (WGMS 2009), (ii) the Swiss Glacier Monitoring Network GLAMOS (BAUdER \& RYSER 2011) and (iii) the Swiss permafrost monitoring network PERMOS (Noetzli \& Vonder Mühll 2010). Within all of these networks new monitoring techniques are being currently developed. They are as follows:

Glacier mass balance measurements using automatic cameras. In 2009, the University of Fribourg (in collaboration with the University of Zurich) initiated a long-term mass balance programme on Findelen glacier (Valais, Switzerland). The aim is to maintain only a minimal mass balance stake network to keep the measurement efforts low and in this manner to assure its long-term continuation. In particular with regard to «efficient» mass balance measurements, a pilot project was initiated using an automatic camera to observe the evolution of the snow line and the snow cover depletion patterns (Figure 1, left). A new approach based on a combination of the observed snowlines with simple modelling allows the determination of the dynamics of glacier mass balance throughout the summer season (Huss et al. 2011). A good agreement with in-situ mass balance measurements and geodetic ice volume changes shows the potential of this method for acquiring mass balance data for remote and large glaciers.

The technique of mass balance determination using automatic cameras is particularly promising in regions with difficult field access. Two automatic cameras were installed in the course of the re-establishment of a glacier monitoring programme at Abramov glacier, Kyrgyzstan, Central Asia, which was interrupted for 12 years after an armed attack in 1999 (Figure 1, right).

\section{Helicopter-borne radar to estimate spatially variable} snow accumulation on glaciers. Snow accumulation in rugged alpine terrain has a high spatial variability at small scales (e.g. LeHNING et al. 2008). Understanding the factors of inhomogeneous snow accumulation is highly important for all fields of cryospheric 
science (e.g. the modelling of glacier mass balance). Helicopter-borne radio-echo sounding is a promising new measurement technique for the monitoring of variable snow accumulation over glaciers. Only a few pilot studies have tested the potential of this technique on Alpine glaciers so far, but the results are promising (e.g. Machguth et al. 2006a).

Helicopter-borne radar is currently being applied and developed further at the University of Fribourg. The radar device is attached to a helicopter flying about $10 \mathrm{~m}$ above the glacier surface. Emitted radar waves with a frequency of $500 \mathrm{MHz}$ are reflected both at the surface of the snow, as well as at the snow-ice interface. This allows the continuous monitoring of snow depth along spatial profiles. Further, it is a considerable improvement on the laborious manual snow probings that are currently employed for determining the winter snow accumulation on Alpine glaciers. Helicopter-borne radar offers the possibility of penetrating more than one annual snow or firn layer in the accumulation area and thus allows measurement of past accumulation rates (e.g. EISEN et al. 2003).

The high spatial resolution of snow depth profiles acquired using helicopter-borne radar allows a better understanding of the processes driving the snow accumulation distribution over glaciers and in high mountain environments in general. These data sets are critical to the development of new models and for a better estimate of winter snow amounts at high elevation. This allows improved water resource management and assessment of glacier change and permafrost evolution.

Automatic Electrical Resistivity Tomography moni-
toring of ground ice content. Electrical Resistivity Tomography (ERT) is a geophysical method to determine the electrical resistivity distribution in the subsurface along a 2-dimensional or 3-dimensional grid. As electrical resistivity is a very good indicator of frozen (high resistivity) or unfrozen (low resistivity) ground conditions, ERT is one of the standard methods to detect permafrost conditions (see HAUCK \& KNeISEL 2008; KNeISEL et al. 2008, and references herein). In addition, repeated ERT measurements (monitoring) are very sensitive to changes in ground ice and liquid water content, as spatial resistivity differences due to different geological materials are assumed to be constant with time (HAUCK 2002). Inter-annual changes in ground ice content, such as during the hot summer 2003, could be detected by this method (Hilbich et al. 2008). However, without automatic and continuous measurements each tomogram has to be recorded manually in the field, making the interpretation dependable on the exact date of the measurement.
A new approach for automated Electrical Resistivity Tomography (A-ERT) was recently developed by HILBICH et al. (2011) for permafrost applications. The system is based on an existing Geotom multi-electrode resistivity instrument (Geolog) and includes a solar panel driven battery and remote data transfer to a base station, where the data are recorded. A first prototype of A-ERT was installed in 2009 at Schilthorn, Swiss Alps, along the same profile where discontinuous measurements exist since 1999 (Figure 2).

The potential benefit of acquiring continuous resistivity data with a regular time interval include process analyses e.g. the exact monitoring of infiltrating water from the melting snow cover which induces the thaw processes in the active layer during a time span of only a few days, and the monitoring of the spatial variability of active layer thawing as opposed to rain-induced infiltration events (Hilbich et al. 2011). It could be concluded that without continuous data it would not be possible to distinguish whether inter-annual variability in minimal ERT data (used as proxy for minimal ice contents) are due to the irregular data acquisition or due to the real inter-annual subsurface conditions.

\section{Monitoring of slope movement and deformation} in permafrost terrain. Fundamental research on mass wasting dynamics in Alpine permafrost terrain (between 2300 and $3000 \mathrm{~m}$ a.s.l.) has been conducted since 2001 mainly in the Western Swiss Alps, in collaboration with the University of Lausanne. Kinematic behaviour of active rock glaciers and landslide occurring in the belt of discontinuous permafrost is investigated by means of different terrestrial and remote sensing techniques. The topography of the region, mainly consisting of north-south oriented valleys is optimal for an application of the InSAR (synthetic aperture radar interferometry) technique to detect and monitor slope motion. Since 2005, several inventories of active landforms, comprising valuable information on both the perimeter and the displacement rate of moving areas have been compiled at a regional scale using a large set of InSAR data (Delaloye et al. 2010b). Current efforts are being put into developing automated techniques to monitor the seasonal surface velocity of rock glaciers and landslides using this remote sensing technique (Barboux et al. 2011). At the same time, terrestrial surveying is continuously carried out on a set of about 30 sites especially by means of time-lapse or continuous GPS measurements (DELALOYE et al. 2010a; Lambiel \& Delaloye 2004).

\subsubsection{Modelling techniques}

In many cryospheric studies models of different complexity and scale are routinely applied. These include mass balance models for glaciers (e.g. Huss et al. 2008; Machguth et al. 2006b; Oerlemans 2001), snow 

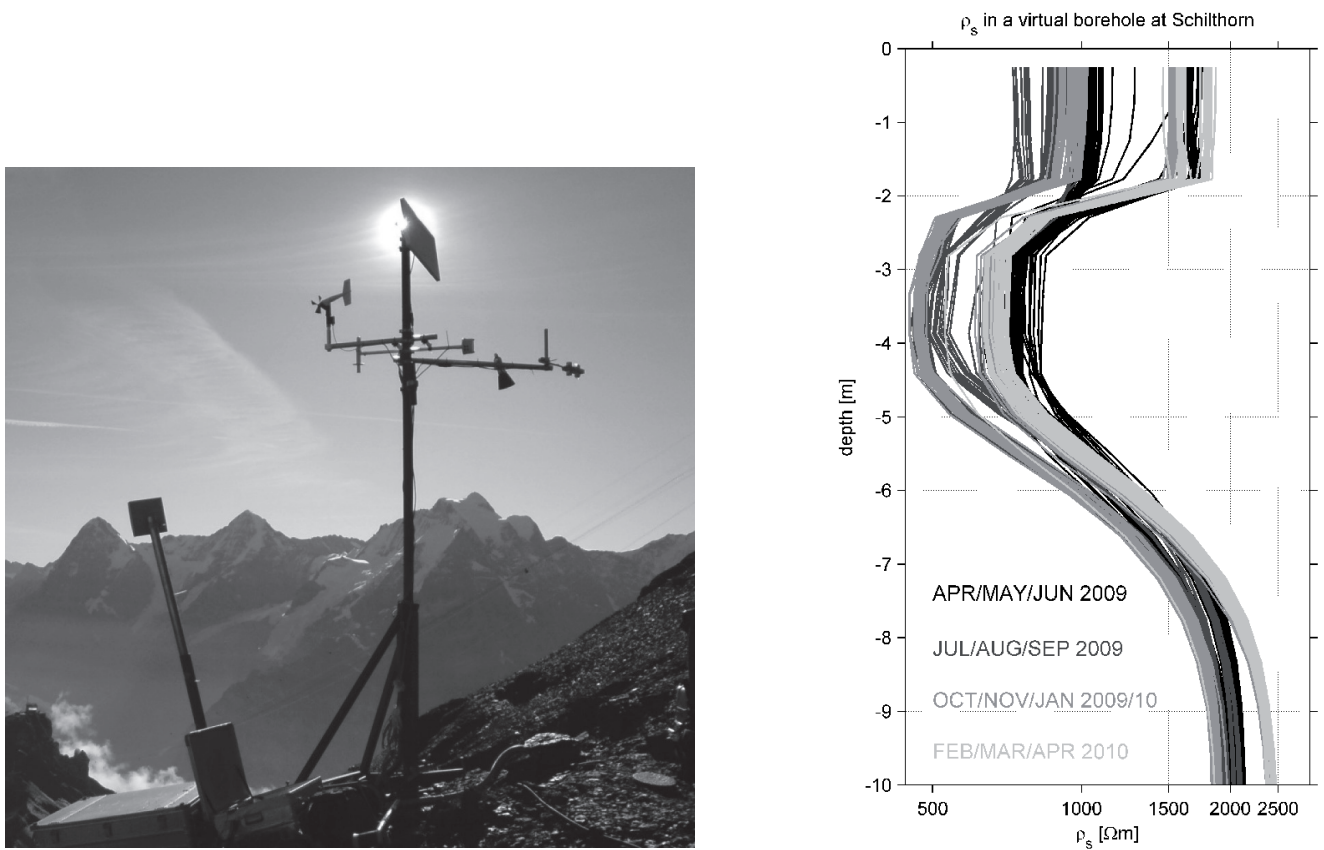

Fig. 2: (left) Meteo station, permafrost borehole and A-ERT installation at the northern slope of Schilthorn, Berner Oberland (2900 m a.s.l.). (right) Monthly specific resistivity values from the inversion results of continuous ERT measurements.

The values are shown along a 1-dimensional profile (a so-called virtual borehole) at the borehole location. Increasing resistivity values correspond to freezing processes, decreasing resistivity values to thawing processes. See also HiLBICH et al. (2011) for more details.

Links: Meteorologische Station, Permafrostbohrloch und A-ERT System im Nordhang des Schilthorns, Berner Oberland (2900 m asl). Rechts: Monatliche spezifische Widerstandswerte aus Inversionsergebnissen der kontinuierlichen ERT Messungen.

Station météorologique, forage dans le permafrost et installation A-ERT sur la face nord du Schilthorn, Oberland bernois (2900 m, à gauche). Valeurs de résistivité mensuelles provenant des résultats des mesures continues ERT (à droite).

Photo: C. HAUCK; figure: C. HiLBICH

models (e.g. LeHNing et al. 2008), permafrost distribution models (see e.g. Hoelzle \& Haeberli 1995; Keller 1992; Noetzli \& Gruber 2009) and Global and Regional Climate Models (GCM, RCM) which include cryospheric components to different degrees (cf. Intergovernmental Panel on Climate Change - IPCC 2007; KotLARSKI et al. 2010a, 2010b). These models are used not only for prediction purposes in the context of global change, but also to identify dominant processes and sensitivities that can be used for model improvements. At the Department of Geosciences, University of Fribourg, models for glacier mass balance and hydrology as well as permafrost process models which can be driven by meteorological observations and/or results from RCMs are being developed and improved. Two examples are presented here:

Glacier Evolution and Runoff Model GERM. With the expected strong climatic changes over the next decades important shifts in the runoff regime of streams originating from glacierised basins are likely. Glaciers are crucial storage elements in the hydrological process system and thus play a pivotal role in determining the timing and the impact of future water stress in mountainous regions and the adjacent lowlands. Current hydrological models are often poorly suited for simulating runoff changes in glacierised basins because they do not represent glaciers as dynamic elements that change their size and stored water volume over time. 


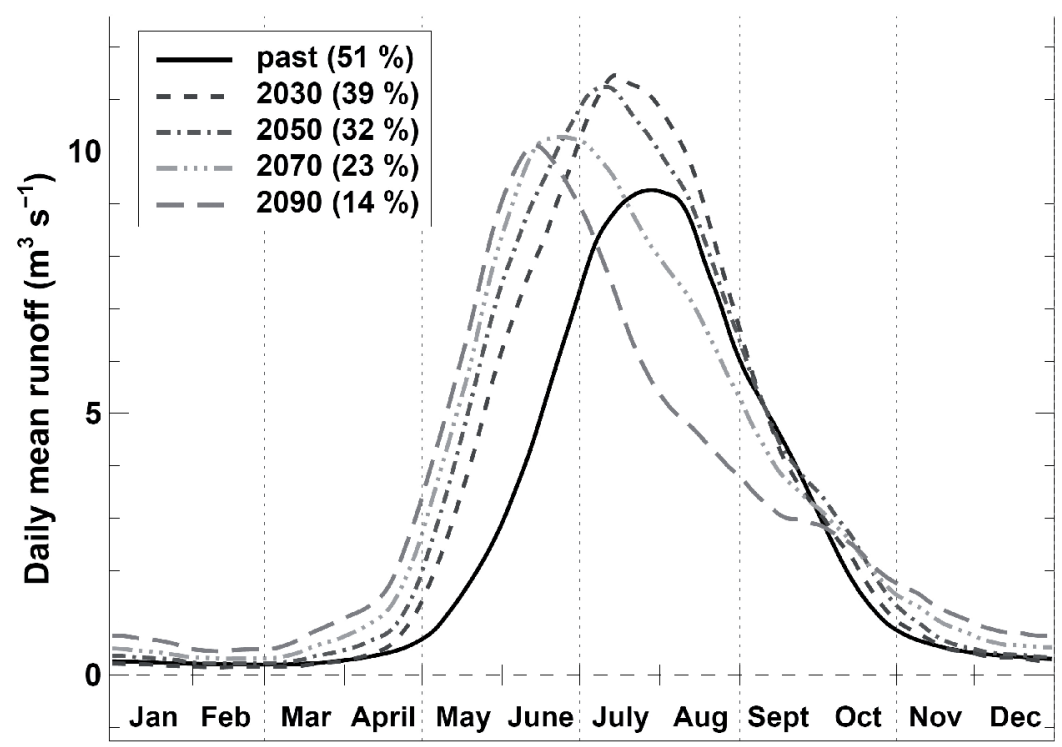

Fig. 3: Projected change in the hydrological regime of the Rhone glacier catchment. Numbers in brackets indicate the glacierisation of the drainage basin.

Modellierte Veränderung des hydrologischen Regimes im Einzugsgebiet des Rhonegletschers. Die zukünftige Vergletscherung des Einzugsgebietes ist durch die Zahlen in Klammern angegeben.

Modélisation des changements du régime hydrologique du bassin du glacier du Rhône. Les nombres entre parenthèses indiquent les taux d'englacement du bassin versant.

Source: Huss et al. 2010

The glacio-hydrological model GERM is an integrative fully distributed model that contains subroutines for all cryospheric components, such as snow accumulation distribution, glacier mass balance, 3D glacier geometry change, permafrost distribution and its spatio-temporal changes, evapotranspiration fluxes and runoff routing (Huss et al. 2008). The model is primarily designed for analysing the future changes in hydrology in glacierised high-mountain basins. The model has been applied to more than a dozen alpine catchments for simulating shifts in the runoff regime over the 21st century (see e.g. FARINOTTI et al., in press; Huss et al. 2010). The results are currently used as an important planning basis by major hydropower companies in Switzerland. In ongoing studies GERM is now also applied in other countries of Europe, as well as in central Asia. The model is continuously being further developed at the University of Fribourg.

Figure 3 shows results of an application of GERM to the highly-glacierised catchment of Rhonegletscher, Valais (Huss et al. 2010). As the glacier strongly retreats over the next decades, thereby releasing the water previously stored as glacier ice, runoff is expected to show an initial increase until about the mid-21st century. Afterwards, a shift in the peak runoff from July/August to June should take place. The runoff regime is thus expected to change from a glacial to a nival type as the glacier virtually disappears leading up to the end of this century. The runoff decrease in the summer months will be most critical to many branches of economy as glaciers represent an important runoff contributor not only in Alpine valleys but also beyond the borders of Switzerland (Huss 2011).

Permafrost application of the coupled heat and mass transfer soil model COUP. Mountain permafrost is a thermal phenomenon depending predominantly on climatic, topographic and soil physical parameters. Especially the timing and duration of the snow cover define the degree of potential impact of changing air temperatures and radiation due to its insolating function on the subsurface. To assess the potential impacts of climate change on subsurface conditions the coupled heat and mass transfer soil model COUP (JANSSON \& KARLBERG 2001) was adapted to mountain permafrost conditions and applied to several permafrost field sites in the Swiss Alps (EngElHARDT et al. 2010; SCHERLER et al. 2010). 
As most permafrost-relevant processes can be simulated with COUP (including the full energy balance at the surface, phase changes in the subsurface, infiltration, refreezing etc), the model can be used for process studies (SCHERLER et al. 2010) as well as sensitivity simulations regarding potential climatic changes (ENGELHARDT et al. 2010). However, as the model calculates heat and mass transfer along 1-dimensional soil columns, advection processes or 3-dimensional effects can only be parameterised.

Forcing data sets were taken from observations (process studies, validation) or from different GCM/RCM projections and de-biased using observation data from meteorological stations. In addition, idealised synthetic data sets, representing seasonal anomalies of air temperature and precipitation based on the reference run were used to analyse the influence of seasonal changes of the dominant meteorological parameters on permafrost conditions. The results show the importance of the timing of the snow cover in autumn and spring and of the air temperatures present before the snow cover arrives in autumn. In addition, and not surprisingly, a linear relationship exists between the air temperatures during the snow free season and their impact on the permafrost temperatures. To a lesser degree the total seasonal precipitation amount influences the permafrost evolution. As the RCM-projected air temperature evolution points to warmer summer and autumns in future, the corresponding impact on the permafrost would be a linear degradation. However, the reduced snow cover in autumn allows for subsurface cooling in early winter, which may have a delayed effect on permafrost degradation, but in a non-linear way (ENGELHARDT et al. 2010).

\subsection{Applicability}

\subsubsection{Natural hazards}

The above monitoring and modelling techniques can be applied to hazard management in the light of glacier retreat, slope deformation, movement and instability (e.g. Fig. 4). In particular, the automatic remote sensing and geophysical monitoring techniques are currently being used to identify slope movements (e.g. BARBOUX et al. 2011) and changes in ground ice content (Hilbich et al. 2008, 2011; IsAKSEN et al. 2011).

\subsubsection{Long-term prediction}

Regarding long-term climate projections a number of projects are currently investigating the potential changes in cryospheric variables, such as snow (SALZMANN \& MEARNS 2012), alpine permafrost (ENGElHARDT et al. 2010), glacier retreat (Jouvet et al. 2011) and water availability (Huss 2011).

Regarding alpine permafrost, combined RCM-permafrost model simulations are currently being conducted within the German-Swiss project cluster SPCC (Sensitivity of Permafrost to Climate Change). RCM projections from the EU ENSEMBLES project are being used to force the COUP subsurface model in idealised permafrost mode. Validation data from the PERMOS stations Schilthorn and Murtèl-Corvatsch in the Swiss Alps were used to verify the model performance during the observation period 2000-2009 (SCHERLER et al. 2011).

The future evolution of Great Aletsch Glacier was simulated using a mass balance model coupled to a 3D ice flow model under different climate scenarios provided by the ENSEMBLES RCMs (Jouvet et al. 2011; Fig. 5). The ENSEMBLES data have also been used for an assessment of the Swiss Alpine glacier's response to a $2^{\circ} \mathrm{C}$ air temperature warming (SALZMANN et al. 2012). A distributed mass balance model is being used to estimate changes in the mass balance, ice volume and length of the major glaciers in the Swiss Alps under a $2^{\circ} \mathrm{C}$ scenario based on an ensemble of RCM data. The chosen modelling approach allows assessing the mass balance model's sensitivity on bias and uncertainties from RCM results.

\section{Future research}

Regarding new monitoring and modelling techniques future research is focused on effective integration of the above mentioned new data acquisition and model systems, especially regarding inter-disciplinary collaborations between the cryospheric community and the adjacent geoscientific communities (e.g. atmospheric sciences, geophysics, hydrology, soil physics, geoarchaeology, human geography).

With respect to permafrost, the evolution of mountain permafrost in Switzerland is currently being analysed in detail to further overall understanding of its vulnerability to climate changes and assess the potential impacts at different field sites in the Swiss Alps (project TEMPS). Two cryospheric variables, i.e. snow and ground ice in particular, have been identified as key coupling variables between atmosphere, permafrost and potential ground deformation and movement.

Regarding the response of mountain glaciers to climate change, the University of Fribourg will continue its monitoring activities on several Swiss glaciers. The intention is to strengthen process understanding by incorporating the whole process chain from climate to glacier reaction, including the analysis of cold temperatures in alpine snow/firn/ice areas, mass balances, length changes, and glacier runoff, in order to refine existing mass balance models. For example, the intention is to extrapolate long-term glacier mass balance 


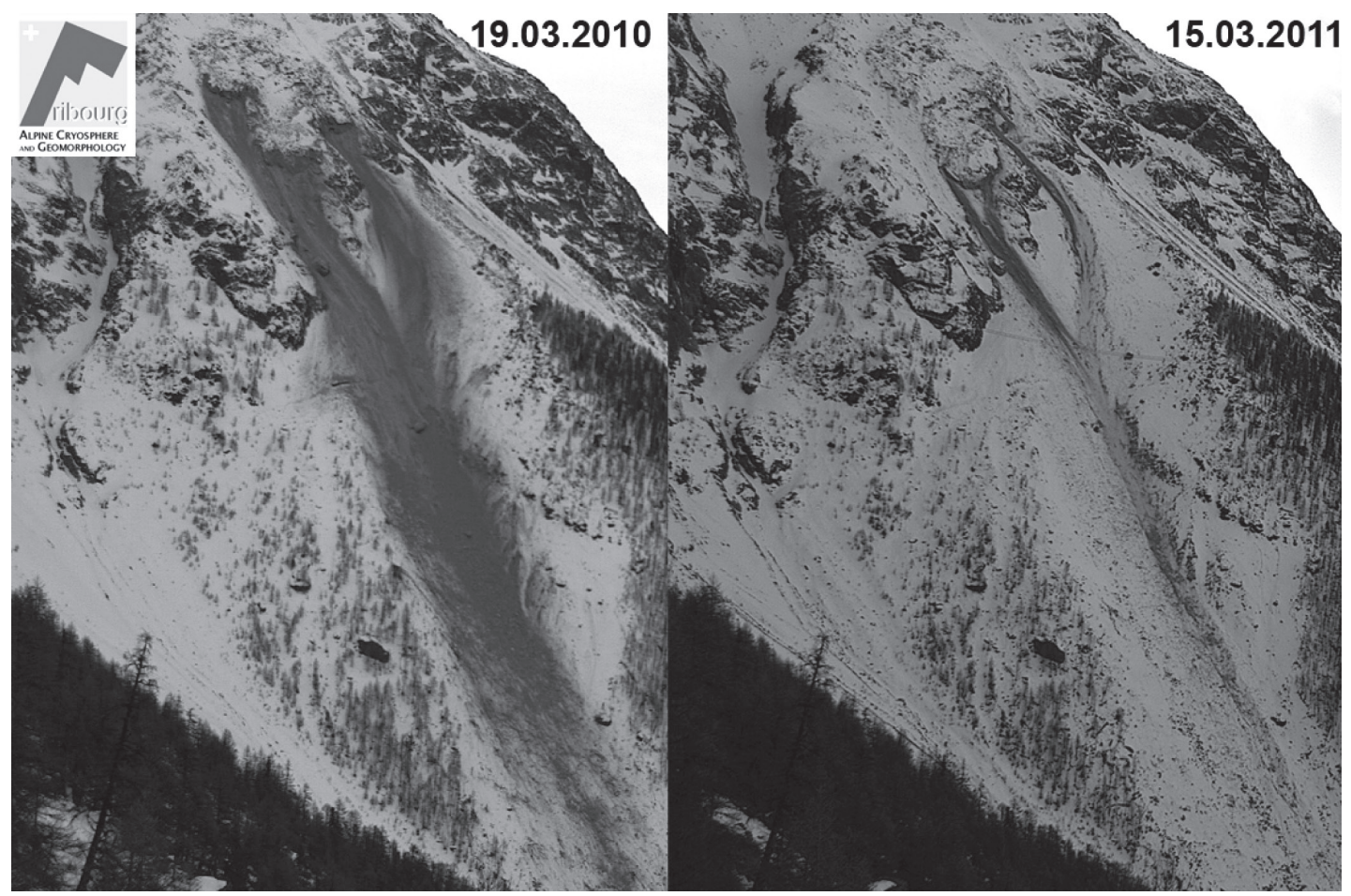

Fig. 4: Surveying erosion processes at the front of the extremely active Grabengufer rock glacier (Randa, VS) by means of an automatic camera

Beobachtung von Erosionsprozessen an der Front des extrem aktiven Blockgletschers Graben Gufer (Randa, Wallis) mit Hilfe einer automatischen Kamera

Surveillance des processus d'érosion sur le front du glacier rocheux du Grabengufer (Randa, VS), extrêmement actif, au moyen d'une caméra automatique

series to the entire European Alps and to include projections of future Alpine-wide glacier change. A second strong focus lies on the impact of glacier retreat on the hydrology of local to continental-scale basins in different glacierised mountain ranges of the earth based on state-of-the-art regional climate model results.

In future, the use of climate related data sets such as reanalysis data will be increasingly used in model studies. Although usually coarse in resolution and thus not directly applicable in high mountain topography, the potential of reanalysis and related datasets would seem to be large as they often represent the only available long-term data in mountain regions. Their actual potential, however, still needs to be further evaluated.

Finally, in addition to joint model and monitoring studies for improving process understanding, the Depart- ment of Geosciences at the University of Fribourg feels dedicated to support and maintain long-term cryospheric observation strategies, which are key to better understanding ongoing and future changes and to ensuring plausible scenario calculations.

\section{Interdisciplinary approaches at Fribourg}

Major scientific progress and improved process understanding requires greater interdisciplinary collaboration. At the University of Fribourg, interdisciplinarity is an important pillar of research. For this reason, the group is involved in several interdisciplinary programmes and improves and makes regular use of integrative research approaches.

An ongoing Swiss National Science Foundation SNSF project in the Geography Unit at the Univer- 


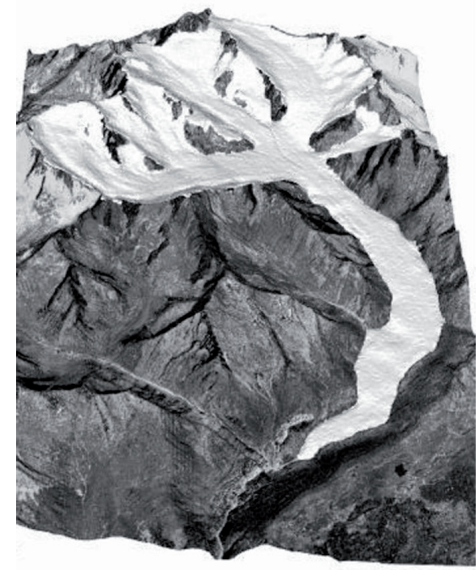

2000

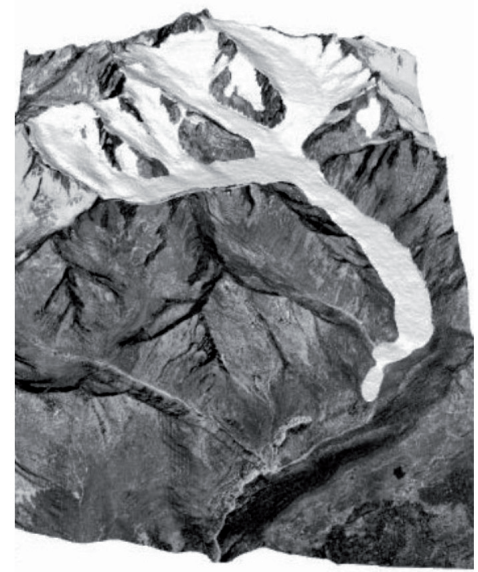

2050

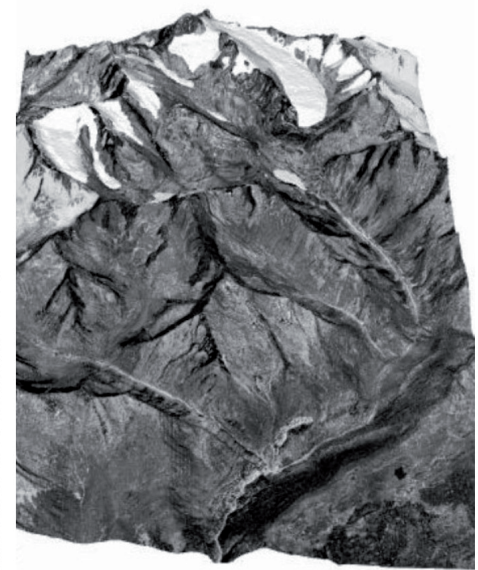

2100

Fig. 5: Modelled glacier retreat of Great Aletsch glacier

A numerical 3D ice flow and mass balance model was forced with temperature and precipitation changes given by ENSEMBLES RCM results. Until the mid-21st century a strong thinning of the glacier tongue is expected, but the change in glacier length is expected to remain relatively small. By 2100 , the glacier will probably have split up into individual branches and the $14 \mathrm{~km}$ long glacier tongue might have completely disappeared.

Modellierter Rückzug des Grossen Aletschgletschers

Modélisation du retrait glaciaire du grand glacier d'Aletsch

Source: JouveT et al. 2011

sity of Fribourg suitably illustrates the potential of new measurement and modelling methods applied in an interdisciplinary project. This project, entitled «Determining high altitude passes and trails in the Alps using GIS tools» involves geographers, historians and archaeologists from different institutions, academic and state agencies from Switzerland and Italy. The objective of the research project is to identify potential archaeological sites in high Alpine regions. The time period of interest ranges from the Neolithic period (over 5000 years ago) through the Roman period into the Middle Ages, where archaeological evidence exists that people used high altitude passes for trade and travel purposes. The study involves the reconstruction of the glacier cover during this period, the identification of potential Alpine passes used for travelling through the Alps, and the assessment of potential paths connecting human settlements. Answers to these questions require the use of geomorphological and climatological models and measurements, the validation of historical documents, and spatial analysis models and methods. Spatial information and results are processed within a geographic database that includes both physical and human layers of geo-referenced information.
A further major effort involving integrative research is currently underway at the Stockhorn/Findelen area, near Zermatt, Western Swiss Alps, where cryo-spheric research is being conducted on a multitude of scales. The idea is to arrange short-term projects around the two long-term monitoring sites (permafrost and energy balance site at Stockhorn and mass balance measurements on Findelen glacier). By using the knowledge and experiences from both sites, and adding those from timelimited projects as described above (e.g. radar measurements), new insights about dependence and interactions between cryospheric processes may become clearer.

The University of Fribourg is furthermore involved in several climate impact and adaptation related international programmes. In the tropical Andes and in Central Asia, glaciers as a fresh water resource are an important socio-economic component. The importance of monitoring glacier retreat and glacier melt has been recognised in recent years also by politicians and decision makers. Consequently, there are at present several activities in progress, including capacity building in glaciology in these countries, initiation of new monitoring programmes, support of ongoing programmes and improvement of collaboration and coordination between these activities. 
Interdisciplinary approaches are also an important aspect of the project MontanAqua in which the University of Fribourg is involved together with the Universities of Berne and Lausanne. MontanAqua aims at assessing future water stress in the region of CransMontana, Valais, in the context of climate change. A particular focus is directed upon the communication of model results to local decision-makers and upon the socio-economic impacts of shifts in water availability. Thus, the combination of physical and human geography approaches in this project reflects the fact that the impacts of environmental change always depend on how the local population deals with them.

\section{Summary}

Thus, in summary, it may be said that research done by the Alpine Cryosphere \& Geomorphology Group in collaboration with the Geomatics Group, University of Fribourg, currently focuses on the development of monitoring and modelling techniques to investigate climate-cryosphere interactions in high mountain areas. Research areas include the Swiss Alps, as well as other cryospheric regions in Central Asia, SouthAmerica and Antarctica. Because of the different components of mountain cryospheres, i.e. snow, permafrost and glaciers, there is a need to develop techniques, monitoring systems and models appropriate for different temporal and spatial scales which allow research of time and temperature dependent mechanisms (phase change of water, deformation of ice and ice/rock mixture, storage of snow/ice, permafrost degradation) as well as of the physical factors controlling sediment transfer (e.g. rock glaciers, debris flows), the hydrological system and the stability of steep slopes.

The following techniques, monitoring systems and models are presented:(i) glacier mass balance measurements using automatic cameras, (ii) helicopter-borne radar to estimate spatially variable snow accumulation on glaciers, (iii) Automatic Electrical Resistivity Tomography (A-ERT) monitoring of ground ice content in permafrost areas, and (iv) the monitoring of slope movement and deformation in permafrost terrain, all of which have been implemented in the cryospheric monitoring networks WGMS (worldwide glaciers), GLAMOS (Swiss glaciers) and PERMOS (Swiss permafrost network). In addition, the Glacier Evolution and Runoff Model GERM and the permafrost application of the coupled heat and mass transfer model COUP are described.

It is emphasised that these new monitoring tools and models and their results can be used in integrative and interdisciplinary studies ranging from process-based investigations to water availability and slope stability issues in the context of climate changes to application in cryospheric studies all over the globe.

\section{References}

Barboux, C., Delaloye, R., Strozzi, T., Collet, C. \& H. RAETzo (2011): TSX InSAR assessment for slope instabilities monitoring in alpine periglacial environment (Western Swiss Alps, Switzerland). - Proceedings of the FRINGE 2011 Workshop, Frascati, Italy, 19-23 September 2011.

Barnett, T.P., Adam, J.C. \& D.P. Lettenmaier (2005): Potential impacts of a warming climate on water availability in snow-dominated regions. - In: Nature 438, doi:10.1038/nature04141.

Bauder, A. \& C. Ryser (eds) (2011): The Swiss glaciers 2005/06 and 2006/07. - Glaciological Report No. $127 / 128$ of the Cryospheric Commission of the Swiss Academy of Sciences, Zurich.

Bommer, C., Phillips, M. \& L.U. Arenson (2010): Practical recommendations for planning, constructing and maintaining infrastructure in mountain permafrost. - In: Permafrost and Periglacial Processes 21, 1: 97-104.

Delaloye, R., Lambiel, C. \& I. Gärtner-Roer (2010a): Overview of rock glacier kinematics research in the Swiss Alps. Seasonal rhythm, interannual variations and trends over several decades. - In: Geographica Helvetica 65, 2: 135-145.

Delaloye, R., Strozzi, T., Lambiel, C., Barboux, C., Mari, S., Stocker, A., Techel, F. \& H. Raetzo (2010b): The contribution of InSAR data to the early detection of potentially hazardous active rock glaciers in mountain areas. - Proceedings ESA Living Planet Symposium, Bergen, Norway, June 28-July 2, 2010, ESA SP-686. Eisen, O., Nixdorf, U., Keck, L. \& D. Wagenbach (2003): Alpine ice cores and ground penetrating radar: combined investigations for glaciological and climatic interpretations of a cold Alpine ice body. - In: Tellus 55B: 1007-1017.

Engelhardt, M., Hauck, C. \& N. Salzmann (2010): Influence of atmospheric forcing parameters on modelled mountain permafrost evolution. - In: Meteorologische Zeitschrift 19, 5: 491-500.

Farinotti, D., Usselmann, S., Huss, M., Bauder, A. \& M. FunK (in press): The runoff evolution in the Swiss Alps: projections for selected high-alpine catchments based on ENSEMBLES scenarios. - In: Hydrological Processes, doi:10.1002/hyp.8276.

Gruber, S. \& W. Haeberli (2007): Permafrost in steep bedrock slopes and its temperature-related destabilization following climate change. - In: Journal of Geophysical Research-Earth Surface 112, F02S18.

Harris, C., Arenson, L.U., Christiansen, H.H., EtzelmÜller, B., Frauenfelder, R., Gruber, S., Haeberli, W., Hauck, C., Hölzle, M., Humlum, O., Isaksen, K., KäÄв, A., Kern-LÜTschg, M., Lehning, M., Mat- 
SuOKa, N., Murton, J.B., NötZli, J., Phillips, M., Ross, N., Seppälä, M., Springman, S.M. \& D. Vonder MÜhll (2009): Permafrost and climate in Europe: monitoring and modelling thermal, geomorphological and geotechnical responses. - In: Earth Science Reviews 92, 3-4: 117-171.

HAUCK, C. (2002): Frozen ground monitoring using DC resistivity tomography. - In: Geophysical Research Letters 29, 21: 2016.

Hauck, C. \& C. Kneisel (eds) (2008): Applied geophysics in periglacial environments. - Cambridge: Cambridge University Press.

Hauck, C., Böttcher, M. \& H. Maurer (2011): A new model for estimating subsurface ice content based on combined electrical and seismic data sets. - In: The Cryosphere 5: 453-468.

Hilbich, C., Hauck, C., Hoelzle, M., Scherler, M., Schudel, L., VölKsch, I., Vonder MÜHLl, D. \& R. MÄUSBACHER (2008): Monitoring mountain permafrost evolution using electrical resistivity tomography: a 7-year study of seasonal, annual, and long-term variations at Schilthorn, Swiss Alps. - In: Journal of Geophysical Research 113, F01S90, doi: 10.1029/2007JF000799.

Hilbich, C., Fuss, C. \& C. Hauck (2011): Automated time-lapse ERT for improved process analysis and monitoring of frozen ground. - In: Permafrost and Periglacial Processes 22, 4:306-319, doi:10.1002/ppp.732. Hoelzle, M. \& W. Haeberli (1995): Simulating the effects of mean annual air temperature changes on permafrost distribution and glacier size. An example from the Upper Engadin, Swiss Alps. - In: Annals of Glaciology 21: 400-405.

Hoelzle, M., Darms, G., LÜthi, M. \& S. Suter (2011): Evidence of accelerated englacial warming in the Monte Rosa area, Switzerland/Italy. - In: The Cryosphere 5:231-243.

Huss M., Stokvis, M. \& M. Hoelzle (2011): Oblique photography for short-term monitoring of glacier mass balance. - In: Geophysical Research Abstracts 13, EGU2011-11705.

Huss, M. (2011): Present and future contribution of glaciers to runoff from macroscale drainage basins in Europe. - In: Water Resources Research 47, W07511, doi:10.1029/2010WR010299.

Huss, M., Jouvet, G., Farinotti, D. \& A. Bauder (2010): Future high-mountain hydrology: a new parameterization of glacier retreat. - In: Hydrology and Earth System Sciences 14: 815-829.

Huss, M., FarinotTi, D., Bauder, A. \& M. Funk (2008): Modelling runoff from highly glacierized alpine drainage basins in a changing climate. - In: Hydrological Processes 22: 3888-3902, doi:10.1002/hyp.7055.

Intergovernmanetal Panel on Climate Change IPCC; Solomon, S., Qin, D., Manning, M., Chen, Z., Marquis, M., Averyt, K.B., Tignor, M. \& H.L. Miller (eds) (2007): Climate change 2007. Contribution of Working Group I to the Fourth Assessment Report of the Intergovernmental Panel on Climate Change. - Cambridge, New York: Cambridge University Press. IsAKSEn, K., ØDEgÅrd, R.S., EtZelmüller, B., Hilbich, C., Hauck, C., Farbrot, H., Eiken, T., Hygen, H.O. \& T. Hipp (2011): Degrading mountain permafrost in Southern Norway: spatial and temporal variability of mean ground temperatures, 1999-2009. - In: Permafrost and Periglacial Processes 22, 4: 361-377.

Jansson, P.E. \& L. Karlberg (2001): Coupled heat and mass transfer model for soil-plant-atmosphere systems. - Stockholm: Royal Institute of Technology, Department of Civil and Environmental Engineering. Jouvet, G., Huss, M., Blatter, H. \& M. FunK (2011): Modelling the retreat of Great Aletschgletscher in a changing climate. - In: Journal of Glaciology 57, 206: 1033-1045.

КӒ̈̈в, А. (2005): Remote sensing of mountain glaciers and permafrost creep. - Zurich: Department of Geography, University of Zurich.

Kä̈̈в, A., Huggel, C., Fischer, L., Guex, S., Paul, F., Roer, I., Salzmann, N., Schlaefli, S., Schmutz, K., Schneider, D., Strozzi, T. \& Y. Weidmann (2005): Remote sensing of glacier- and permafrost-related hazards in high mountains: an overview. - In: Natural Hazards and Earth System Sciences 5, 4: 527-554.

KäÄB, A., Chiarle, B., Raup, B. \& C. Schneider (2007): Climate change impacts on mountain glaciers and permafrost. - In: Global and Planetary Change 56, 1-2: vii-ix.

KeLLER, F. (1992): Automated mapping of mountain permafrost using the program PERMAKART within the Geographical Information System ARC/INFO. In: Permafrost and Periglacial Processes 3, 2: 133-138.

Kneisel, C., Hauck, C., Fortier, R. \& B. Moorman (2008): Advances in geo-physical methods for permafrost investigation. - In: Permafrost and Periglacial Processes 19: 157-178.

Kotlarski, S., Jacob, D., Podzun, R. \& F. Paul (2010a): Representing glacier in a regional climate model. - In: Climate Dynamics 34, 1: 27-46.

Kotlarski, S., Paul, F. \& D. Jacob (2010b): Forcing a distributed glacier mass balance model with the regional climate model REMO, part I: climate model evaluation. - In: Journal of Climate 23, 6: 1589-1606.

Kulessa, B. \& J. Woodward (2007): Introduction to the special issue of JEEG: the geophysics of glacial and frozen materials. - In: Journal of Environmental \& Engineering Geophysics 12, 1:1-2.

Lambiel, C. \& R. Delaloye (2004): Contribution of real-time kinematic GPS in the study of creeping mountain permafrost: examples from the Western Swiss Alps. - In: Permafrost and Periglacial Processes 15, 3: 229-241.

Laternser, M. \& M. Schneebeli (2003): Long-term snow climate trends of the Swiss Alps (1931-99). - In: International Journal of Climatology 23, 7: 733-750. LehNing, M., LÖWE, H., Ryser, M. \& N. Raderschall 
(2008): Inhomogenous precipitation distribution and snow transport in steep terrain. - In: Water Resources Research 44, W07404, doi:10.1029/2007WR006545.

Machguth, H., Eisen, O., Paul, F. \& M. Hoelzle (2006a): Strong spatial variability of snow accumulation observed with helicopter-borne GPR on two adjacent Alpine glaciers. - In: Geophysical Research Letters 33, L13503, doi:10.1029/2006GL026576.

Machguth, H., Paul, F., Hoelzle, M. \& W. Haeberli (2006b): Distributed glacier mass balance modelling as an important component of modern multi-level glacier monitoring. - In: Annals of Glaciology 43, 1: 335-343.

Machguth, H., Kotlarski, S., Hoelzle, M., Paul, F. \& W. HAeberLi (2009): Calculating distributed glacier mass balance for the Swiss Alps from RCM output: a methodical description and interpretation of the results. - In: Journal of Geophysical Research 114, D19106, doi:10.1029/2009JD011775.

Noetzli, J. \& S. Gruber (2009): Transient thermal effects in Alpine permafrost. - In: The Cryosphere 3: 85-99.

Noetzli, J. \& D. Vonder Mühll (eds) (2010): Permafrost in Switzerland 2006/2007 and 2007/2008. - Glaciological Report (Permafrost) No. 8/9 of the Cryospheric Commission of the Swiss Academy of Sciences, Zurich. OerLemans, J. (2001): Glaciers and climate change. Rotterdam: Balkema.

Paul, F. \& S. Kotlarski (2010): Forcing a distributed mass balance model with the regional climate model REMO, part II: downscaling strategy and results for two Swiss glaciers. - In: Journal of Climate 23, 6: 16071620.

Salzmann, N. \& L.O. Mearns (2012): Assessing the performance of multiple regional climate model simulations for seasonal mountain snow in the Upper Colorado River Basin. - In: Journal of Hydrometeorology 13, 2: 539-556. doi: http://dx.doi. org/10.1175/2011JHM1371.1.

Salzmann, N., Machguth, H. \& A. Linsbauer (2012): The Swiss alpine glacier's response to the $\ll 2^{\circ} \mathrm{C}$ air temperature target». - In: Geophysical Research Abstracts 14, EGU2012-10226.

Scherler, M., Hauck, C., Hoelzle, M., Stähli, M. \& I. VölKsch (2010): Melt-water infiltration into the frozen active layer at an alpine permafrost site. - In: Permafrost and Periglacial Processes 21, 4: 325-334.

Scherler, M., Hauck, C. \& M. Hoelzle (2011): Projection of permafrost and snow cover evolution under climate change scenarios. - In: Geophysical Research Abstracts 13, EGU2011-11807.

Stahl, K., Moore, R.D., Shea, J.M., Hutchinson, D. \& A.J. CANnon (2008): Coupled modelling of glacier and streamflow response to future climate scenarios. - In: Water Resources Research 44, W02422, doi:10.1029/2007WR005956.

Strozzi, T., Delaloye, R., Kääв, A., Ambrosi, C., Perruchoud, E. \& U. Wegmüller (2009): Combined observations of rock mass movements using satellite SAR interferometry, differential GPS, airborne digital photogrammetry and airborne photography interpretation. - In: Journal of Geophysical Research, doi:10.1029/2009JF001311.

World Glacier Monitoring Service - WGMS (ed.) (2009): Glacier mass balance bulletin no. 10. - Zürich: World Glacier Monitoring Service.

\section{Abstract: The potential of new measurement and modelling techniques in alpine cryosphere and geomorphology research}

The high-mountain cryosphere, in particular snow, permafrost and glaciers, plays a key role regarding climate change impacts on mountain ecosystems because of (i) its high climate sensitivity due to the proximity to the melting point, (ii) its major controlling function on hydrological runoff, and (iii) particularly because of the influence of seasonal snow on ground-atmosphere processes. In order to reliably assess the influence of climatic changes on the cryosphere and consequently their impacts on society, more detailed knowledge of the relevant processes that determine the interactions between the alpine cryosphere and the atmosphere on different spatial and temporal scales is required. As cryospheric changes in high mountains are strongly coupled to geomorphic processes these may result in dramatic changes in response to ongoing and future climatic evolution.

Temperature dependent mechanisms (e.g. phase change of water, deformation of ice and ice/rock mixture, storage of snow/ice, permafrost degradation) will affect the physical factors controlling the transfer of sediment (e.g. glaciers, rock glaciers, debris flows), the hydrological system and the stability of steep slopes. Research in alpine cryosphere and geomorphology at the University of Fribourg particularly focuses on the development of new measurement and modelling techniques to investigate and monitor mountain periglacial and glacial systems, including process-based modelling studies, monitoring strategies, and analyses of the impact on hydrology and natural hazards. In this contribution, the potential of these new modelling, measurement and analysis techniques for fundamental and applied research on mountain regions in Switzerland is presented.

Keywords: alpine cryosphere and geomorphology, processes, modelling, monitoring, climate change

\section{Zusammenfassung: Das Potential von neuen Mess- und Modelliermethoden in der alpinen Kryosphären- und Geomorphologie-Forschung}

Die Hochgebirgs-Kryosphäre, insbesondere Schnee, Permafrost und Gletscher, spielt in Bezug auf die 
Auswirkungen eines sich ändernden Klimas auf die Gebirgsökosysteme eine Schlüsselrolle aufgrund (i) ihrer starken Sensitivität infolge von Temperaturen nahe dem Schmelzpunkt, (ii) ihrer Funktion als (Haupt-) Steuerungsgrösse des hydrologischen Abflusses und (iii) des Einflusses von Veränderungen bezüglich der saisonalen Schneedecke, da diese Boden-Atmosphäre Wechselwirkungen auf verschiedene Weise stark beeinflusst. Um den Einfluss des Klimawandels auf die Kryosphäre und die damit verbundenen Auswirkungen für die Gesellschaft verlässlich bestimmen zu können, ist ein besseres Verständnis der für die Wechselwirkungen zwischen alpiner Kryosphäre und Atmosphäre relevanten Prozesse auf verschiedenen räumlichen und zeitlichen Skalen vonnöten. Da Veränderungen der Kryosphäre im Hochgebirge mit geomorphologischen Prozessen gekoppelt sind, können diese zu Naturgefahren aufgrund aktueller und zukünftiger Klimaänderungen führen.

Temperaturabhängige Prozesse (z.B. Phasenübergänge von Wasser, Deformation von Eis sowie Eis/ Fels-Gemischen, Vorrat an Schnee/Eis, Permafrostdegradation) beeinflussen die physikalischen Faktoren, die den Sedimenttransport steuern (z.B. Gletscher, Blockgletscher, Murgänge), das hydrologische System sowie die Stabilität steiler Hänge. Aktuelle Forschungen an der Universität Freiburg im Bereich der alpinen Kryosphäre und Geomorphologie beschäftigen sich insbesondere mit der Entwicklung neuer Messund Modelliermethoden, um periglaziale und glaziale Systeme in Gebirgsregionen zu untersuchen und langfristig zu beobachten. Dies beinhaltet prozess-basierte Modellstudien, Monitoringstrategien sowie ImpactStudien in Bezug auf Hydrologie und Naturgefahren. In diesem Beitrag wird das Potential dieser neuen Modellier-, Mess- und Auswertungsmethoden für die Grundlagenforschung und ihrer Anwendung in den Gebirgsregionen der Schweiz vorgestellt.

Schlüsselwörter: alpine Kryosphäre und Geomorphologie, Prozesse, Modellierung, Monitoring, Klimaänderung

\section{Résumé: Le potentiel des nouvelles mesures et tech- niques de modélisation dans la cryosphère alpine et la recherche géomorphologique}

La cryosphère de haute altitude (neige, permafrost et glaciers) joue un rôle majeur sur le changement climatique des écosystèmes de montagne, en raison de (i) sa forte sensibilité climatique due à la proximité au point de fusion, (ii) sa fonction de contrôle des écoulements hydrologiques, et (iii) de l'influence particulière des processus saisonniers liés à l'enneigement et à l'atmosphère terrestre. Afin d'évaluer de manière fiable l'influence du changement climatique sur la cryosphère et son impact sur la société, une meilleure compréhension des processus à l'œuvre entre la cryopshère alpine et l'atmosphère est nécessaire, à différentes échelles spatiales et temporelles. Le fait que les changements cryosphériques en haute montagne soient fortement liés aux processus géomorphologiques peut conduire à des changements spectaculaires dans le contexte climatique actuel et futur.

Les mécanismes dépendants de la température comme les différentes phases de l'eau, la déformation de la glace et du mélange glace-roche, le stockage de la neige et de la glace ou les dégradations du permafrost affecteront les facteurs physiques qui contrôlent le transfert de sédiments (glaciers, glaciers rocheux, éboulements), le système hydrologique et la stabilité des fortes pentes. La recherche sur la cryosphère alpine et en géomorphologie de l'Université de Fribourg se concentre en particulier sur le développement de nouvelles mesures et techniques de modélisation, qui permettent d'analyser et de surveiller les systèmes glaciaires et périglaciaires. Ce champ de compétences comprend également la modélisation des processus, les stratégies de surveillance et les analyses de l'impact sur les risques hydrologiques et naturels. Cette contribution présente le potentiel de ces mesures, modélisations et techniques d'analyse pour la recherche fondamentale et appliquée portant sur les régions de montagne de Suisse.

Mots-clés: cryosphère alpine et géomorphologie, processus, modélisation, surveillance, changement climatique

Prof. Dr. Christian Hauck, Prof. Dr. Claude Collet, Prof. Dr. Reynald Delaloye, Dr. Christin Hilbich, Prof. Dr. Martin Hoelzle, Dr. Matthias Huss, Dr. Nadine Salzmann, Department of Geosciences, University of Fribourg, Chemin du Musée 4, CH-1700 Fribourg, Switzerland.

e-mail:

christian.hauck@unifr.ch

claude.collet@unifr.ch

reynald.delaloye@unifr.ch

christin.hilbich@unifr.ch

martin.hoelzle@unifr.ch

matthias.huss@unifr.ch

nadine.salzmann@unifr.ch

\section{Manuskripteingang/received/manuscrit reçu le 25.9.2011 \\ Annahme zum Druck/accepted for publication/accepté pour publication: 15.5 .2012}

